So great is the part played by bacteria in determining fertility, that a great amount of attention is being paid in most soil laboratories to their various actions. The fixation of nitrogen is of perennial fascination, and is still far from being solved. Certain bacteria, notably azotobacter, can take up gaseous nitrogen and synthesise protein, nuclein, \&c., without any materials save only sugar and various mineral salts. The organisms occur in most soils, and it is only necessary to inoculate small quantities of soil into a solution containing the sugar, phosphates, potassium and other salts, but no nitrogen compounds, for development to take place and nitrogen fixation to occur. The chemistry of the process is unknown; investigation, so far, has been confined almost entirely to morphological work and to the effect of various conditions on the process. Messrs. C. Hoffmann and B. W. Hammer, of the University of Wisconsin Agricultural Experiment Station, have recently (Research Bulletin 12) repeated and extended some of these observations. They find the best sugars are mannite and lactose, but it is not desirable to have too much. Similarly, there is no advantage in having too much calcium carbonate, although some is needed. In one respect these authors differ from previous investigators; on analysing the dry azotobacter cells they obtained a protein content of $17 \cdot 75$ per cent. only, against 80 per cent. found by Gerlach and Vogel and 70.6 per cent. by Stoklasa. The cause of the difference is not clear, but may perhaps be ascribed to the slime that invariably surrounds the organism without being an integral part of it, and that is only removed with great difficulty.

How far azotobacter is active in the soil is difficult to determine, because there is an opposite process, the liberation of gaseous nitrogen from protein, and also, under anærobic conditions, from nitrates, also brought about by bacteria. But it has been shown by Koch that the addition of sugar to soil some months before the seed was sown led to an increase in crop by increasing nitrogen fixation, although if applied direct to the crop it produced harmful results. These facts are attracting much attention in sugar-producing countries, and it has been shown that waste molasses, which cannot profitably be sold, gives useful increases in crop when applied as manure some weeks before planiting, especially on light soils. S. S, Peck, of the Hawaiian Sugar Planters' Experiment Station (Bulletin 34), has studied the two changes, nitrogen fixation and denitrification, and confirms the general results already obtained; molasses applied before planting stimulates nitrogen fixation, but applied to the growing plant it does harm by causing loss of nitrate or diminished nitrification.

He also confirms some recent work of Russell and Hutchinson, and finds that numbers of protozoa harmful to bacteria occur in soil-he found amøbæ, paramecium, and others-all of which can be destroyed by moderate heat or antiseptics like carbon disulphide. Partial sterilisation of the soil is being studied in several directions. The Journal of Agriculture of South Australia states that farmers there have long recognised the advantage of burning the stubbles, and thus heating the soil; investigations are in hand at the Roseworthy Agricultural College to study the problem from this new point of view. An apparatus for soil sterilisation suitable for gardeners is described in The Journal of the Department of Agriculture of Victoria, which is similar in principle to some that are working in England. The Scientific American recently gave an account of methods proposed in the United States.

Although nitrates are invaluable in the soil, an excess is injurious, because it causes plasmolysis. Dr. Headden, of the Colorado Agricultural College Experiment Station (Bulletins 155 and 160 ), reports analyses of soils in Colorado containing such excessive amounts of nitrates that they were sterile. He thinks their formation can be explained only as due to bacteria; he supposed that nitrogen fixation has gone on to an excessive degree, and has thus led to disastrous consequences. Further work on these soils will be awaited with interest.

The factors determining soil fertility are slowly being disentangled, but they are far from being fully known, and therefore investigations of cases of infertility are of considerable scientific interest, besides being of technical importance. Such a case is afforded by the scouring NO. 2 I67, VOL. 867 pastures of Somerset, now being studied by $C$. $T$. Gimingham, of the University of Bristol. Pastures in certain districts of the Lower Lias formation cause diarrhœa or "scouring" in cattle fed on them. No obvious explanation is forthcoming, no poisonous weeds are found, nor does the provision of a pure water supply obviate the trouble. Mr. Gimingham has, in The Journal of the Board of Agriculture (No. 7), collected the main facts, and adduces strong evidence to show that the physical condition of the soil is the determining factor, the peculiar conditions obtaining on the Lower Lias, but not on the adjacent alluvium and Inferior Oolite, being favourable to the factor actually causing the disease. Experimental work on this subject is necessarily slow and tedious, but, in view of its importance, it is much to be hoped that Mr. Gimingham will be able to continue the work on the sound lines on which he has begun.

The phenomena of flocculation and deflocculation in soils have been much investigated, but are far from being worked out. E. E. Free has recently summarised (Journal of the Franklin Institute) the present position of our knowledge, and has shown that a marked infuence is exercised by impurities present in the water in which the suspensions are made for experimental purposes. He considers it probable that in absolutely pure water only a medium degree of permanence would be attained. In his view, any material can be suspended in water, flocculated, and deflocculated, if it can be got in a sufficiently fine state.

E. J. Russell.

\section{MUSEUM WORK IN INDIA AND AFRICA.}

$A$ CCORDING to the report of the Natural History Section, the year 1909-10 was an important one in the development of the Indian Museum, Calcutta, as it : $v$ itnessed not only a reorganisation of the staff of that section, but likewise the passing of an Act to give greater independence to the constituent ctions in the matter of scientific and educational work, and also to permit the respective chiefs of the same to become ex officio members of the board of trustees. As a result of the new regulations, it will be possible to separate the archæological from the zoological section, and to place the former under the control of the director of the Archæological Survey Among the additions during the year, attention is directed to the cast of a susu, or river-dolphin, from the Hughli.

The report on the fishes collected by the Golden Crown is continued, by Messrs. Annandale and Jenkins, in No. I of the third volume of the Memoirs of the Indian Museum, these contributions including a supplementary note on the rays, together with accounts of the Plectognathi, Pediculati, and flat-fishes. As the collection of sharks made by the Golden Croren was relatively small, the consideration of that group is postponed. The teleostean collection, on the other hand, is so extensive that its description in an adequate manner will practically mean a revolution in our ideas of the Indian marine fish-fauna. In the present contribution three small and compact groups, to which the additions are comparatively few, have been selected for treatment.

From among nine papers on various groups of invertebrates in the fourth part of vol. v. of the Records of the Indian Museum it must suffice to refer to some interesting information, by Messrs. Henderson and Mathai, on the occurrence of dimorphism in certain fresh-water prawns of the genus Palrmon. In many, if not all, the species two forms of adult males occur, namely, a normal type of relatively large size, with well-developed nippingclaws, and a generally smaller type, with the same claws no bigger than in females. Among certain other decapods in which a similar dimorphism obtains, the two phases are recurrent, and severally represent the breeding and non-breeding conditions; but, so far as the authors of the paper could ascertain, this does not appear to be the case with the Indian Palæmons.

The classification of the anopheline mosquitoes of India forms the subject of No. 5 (it may be noted that "part" and "No." are respectively used in the two issues) of vol. iv. of the serial last quoted. The changes proposed are of a radical character, the author, Major S. P. James, refusing to admit that any of the species are referable to the typical Anopheles. The Indian members of the group 
are divisible into two series, respectively characterised by the presence or absence of scales on the abdomen.

To the Annals-which now bear the alternative title of Mededeelingen - of the Transvaal Museum for November, IgIo, Mr. J. Hewitt contributes a key to the South African members of four families of lizards, with notes on their distribution. The issue is also noteworthy on account of the inclusion of eight beautifully coloured plates to illustrate Mr. Meyrick's article on Microlepidoptera published in an earlier part.

\section{REPORT OF THE BOARD OF EDUCATION.}

THE report of the Board of Education for the year 1909-10, published a few days ago (Cd. 5616 , price 8d.), contains an instructive statement of the position of elementary, secondary, and technical education in England. One section of the report, dealing with the teaching of science in secondary schools, was reprinted in NATURE of May 4 (p. 326), and we now give an abstract of other portions. The section of the report devoted to elementary education reviews the history and recent development of the provision made for teaching the pupils in public elementary schools, and touches upon certain aspects of the subject of school staffing which have been especially prominent very recently. With this subject we are not particularly concerned in these columns, but the subjoined extracts, relating chiefly to higher education, will interest readers of NATURE.

\section{Establishment of the Universities Branch of the Board.}

The Board has recently organised a special branch of its department to deal with the many matters arising from the connection with the work done by the modern universities. Experience had shown that the technological and professional instruction (including the training of teachers for elementary and for secondary schools) given by the universities and aided by grants from the Board, could not be properly dealt with as part of the ordinary administration of the Board as applied to institutions which have less autonomy, responsibility, and prestige than the universities. The universities need the greatest possible degree of freedom in organising and carrying out their important national and international functions, and the Board has for long been convinced that their relations with the universities should be so adjusted as to further this end. In April, 1910, the President accordingly appointed the Board's director of special inquiries and reports, Mr. H. F. Heath, to the office of principal assistant secretary for the new universities branch of the Board. Mr. Heath had a long connection with, and an intimate knowledge of, the modern universities before his appointment to the Board in 1903 , and his work in the Board's staff as an advisory rather than an administrative officer since that date marked him out as specially qualified for the new post. $\mathrm{Mr}$. Heath continues to hold his office as director of special inquiries and reports.

The International Commission on the Teaching of Mathematics.

In view of the fact that a meeting of the International Congress of Mathematicians is to be held at Cambridge in 1912, and that an International Commission on the Teaching of Mathematics has been constituted in connection with the educational section of the congress, the office of special inquiries and reports has made arrangements to publish a series of papers dealing with the teaching of mathematics. It is intended that copies of these papers shall be placed at the disposal of the International Commission, and that they shall ultimately form a volume or volumes in the series of special reports on educational subjects.

An advisory committee has further been appointed by the President of the Board to assist in the collection of papers and to advise as to the suitability of the contributions sent in. This committee will also act as the British Subcommission-one of a number of national subcommissions rstablished to assist the International Commission in its work-and is constituted as follows:-Mr. C. E. Ashford, Sir G. H. Darwin, K.C.B., F.R.S., Prof. G. A. Gibson, Mr. C. Godfrey. Sir George Greenhill, F.R.S., Mr. F. H. Hardy, F.R.S., Prof. E. W. Hobson, F.R.S., No. 2 I67, VOL. 867
Mr. C. S. Jackson, Sir Joseph Larmor, M.P., F.R.S., Prof. A. E. H. Love, F.R.S.

Mr. C. S. Jackson is honorary secretary to the British Subcommission.

\section{The Science Museum.}

The needs of the Science Museum have been before the Board for some years, and it has recently become possible to take active steps to provide for them. The matter formed the subject of a memorial of great weight, presented just a year ago by a deputation representing the learned societies, the universities, and the technical colleges of the country; and the evidence then put before the Board amply confirmed the view that the science collections are even now of great value to the nation, but that their usefulness is crippled, and their growth prevented, by the inadequacy of the buildings in which they are housed.

The accommodation for these rich collections, which include many inventions that have proved to be pioneers in industrial arts and afford much effective exposition of modern developments of pure and applied science, ought to be in every way worthy of the interests. which they serve. What has now to be done to meet this requirement ought to be done on a scale and in a form that will give the Science Museum an assured place among the permanent national institutions of the country. The Board is anxious that the scheme for the future development of this museum should receive adequate consideration before the work is actually put in hand, and it feels that the requirements of the collections in the Museum of Practical Geology in Jermyn Street should be discussed at the same time. In whatever action it may take in this matter, it wishes to assign to the valuable collections in these two museums definite part in the provision of facilities by nationai museums. A Departmental Committee was therefore appointed in March, I9Io, to consider and report upon various questions in regard to the collections. In particular the committee was asked "to advise (a) as to the precise educational and other purposes which the collections can best serve in the national interests; $(b)$ as to the lines on which the collections should be arranged and developed, and possibly modified, so as more effectively to fulfil these purposes; and $(c)$ as to the special characteristics which should be possessed by the new buildings, which it is hoped will shortly be erected on the South Kensington site to house these collections, so as to enable the latter to be classified and exhibited in the manner most fitted to accomplish the purposes they are intended to fulfil." [See NATURE, May 4.]

The committee informed the Board in a preliminary report in July last as to the general conclusions it had then reached on these questions, and in particular as to the nature and extent of the collections and as to the size of the buildings that would be required for such a development of the collections as they contemplated. The Royal Commission for the Exhibition of $185 \mathrm{I}$ has intimated that it is prepared to make a grant of $100,000 l$. from the funds at its disposal towards the erection of a new building for the museum, the balance of the cost of which would be provided from public funds.

$$
\text { Secondary Schools (England). }
$$

The total number of schools regarded as eligible for grant during $1909-10$ was $84 \mathrm{I}$, as compared with 804 during 1908-0. Of these, 325 were controlled by local authorities, 447 were endowed schools or schools of a similar type, 29 were schools belonging to the Girls' Public Day School Trust, and 40 were controlled by Roman Catholic teaching orders. In these schools there were on January 31, 1910, 76,009 boys and 64,649 girls, as compared with 73,273 boys and 62,401 girls on January 31 , I909.

In addition to the $84 \mathrm{~T}$ schools on the grant list there were 87 other schools recognised by the Board as efficient during I009-10, being an increase of 5 on the number recognised as efficient during 1908-a. Of these 67 were endowed schools or schools of a similar type, 3 were controlled by Roman Catholic teaching orders, and I7 were private schools. In these schools there were on January $3 \mathrm{I}$, I9I0, 8215 boys and 7249 girls, as compared with 7 117 boys and $7 \mathrm{~s} 79$ girls on October I, 1908 .

Thus during the year I909-10 there were in England altogether 928 schools recognised by the Board as efficient, educating 85,124 boys and 71,898 girls, as compared with 